\title{
A NEW AND NOTEWORTHY SPECIES OF DIOSCOREA (Dioscoreaceae) from Michoacán, MeXico
}

\author{
Yocupitzia Ramírez-Amezcua ${ }^{1}$, Oswaldo Téllez ${ }^{2}$, and Victor Werner Steinmann ${ }^{1,3}$ \\ 'Instituto de Ecología, A.C., Centro Regional del Bajío, Pátzcuaro, Michoacán, México \\ ${ }^{2}$ Laboratorio de Recursos Naturales UBIPRO, Facultad de Estudios Superiores Iztacala \\ Universidad Nacional Autónoma de México, Tlalnepantla, Edo. de México, Mexico \\ ${ }^{3}$ Author for correspondence: victor.steinmann@inecol.edu.mx
}

\begin{abstract}
The new species Dioscorea megaphylla (Dioscoreaceae) is described and illustrated with photographs. It is known only from the type locality, along the coastal foothills of the Sierra de Coalcomán in the municipality of Aquila, Michoacán, Mexico, where it grows in rocky canyons and hillsides with tropical subdeciduous forest at elevations of 550-600 m. As the specific epithet suggest, this species is distinctive due to the size of its leaves, and these are the largest within the genus Dioscorea and measure as much as $60 \mathrm{~cm}$ long and $65 \mathrm{~cm}$ wide. Unlike most members of the genus, flowering occurs at the end of the dry season on newly produced stems before the leaves mature. Dioscorea megaphylla belongs to sect. Macrogynodium and is closely related to D. nelsonii and D. carpomaculata.
\end{abstract}

Key words: Disocorea, Mexico, section Macrogynodium.

Resumen: Se describe e ilustra Dioscorea megaphylla (Dioscoreaceae) como especie nueva. Se conoce solamente de la localidad tipo, en montañas bajas de la parte sur de la Sierra de Coalcomán, municipio de Aquila, Michoacán, México, donde crece en laderas y cañadas rocosas con bosque tropical subcaducifolio a elevaciones de 550-600 m. Como el epíteto específico lo indica, la especie se distingue por el tamaño de sus hojas, que son las más grandes del género Dioscorea y llegan a medir hasta $60 \mathrm{~cm}$ de largo y 65 $\mathrm{cm}$ de ancho. A diferencia de la mayoría de los miembros del género, la floración se presenta al final de la temporada seca y en tallos nuevos antes de que las hojas se desarrollen. Dioscorea megaphylla pertenece a la sección Macrogynodium y está cercanamente emparentada con D. nelsonii y D. carpomaculata.

Palabras clave: Disocorea, México, sección Macrogynodium.

$\mathbf{T}$ he genus Dioscorea L. is by far the largest in the family Dioscoreaceae, although the total number of species is still not satisfactorily known. Knuth (1924) estimated approximately 640 species, whereas Al-Shehbaz and Schubert (1989) calculated as many as 900 species. More recently, Caddick et al. (2002) proposed that the genus could be comprised of as few as 350 species, and Govaerts et al. (2007) listed 644 species. Furthermore, in addition to discrepancies in the number of species, there is still much work remaining to evaluate and assess the monophyly and delimitation of many infrageneric taxa.

Independent of the uncertainties about the size of the genus as a whole, there are 73 known species of Dioscorea in Mexico, and the country is a tertiary center of diversity (Téllez-Valdés and Geeta, 2007b), after Brazil (250 species), and Peru (80 species). About $60 \%$ of these are en- demic to Mexico, and they occur in both tropical and temperate habitats, with the majority flowering during the rainy season from June to October. There are many field and herbarium studies on the Mexican species (e.g., Matuda, 1953; Schubert, 1989; Téllez-V. and Schubert, 1987, 1996; TéllezValdés and Schubert, 1991; Téllez, 1997; Govaerts et al., 2007; Téllez-Valdés and Geeta, 2007a, b), and these have resolved many of the taxonomic problems; there is also a recent phylogenetic study of the genus (Walls, 2009). These contributions greatly facilitate the determination of material and have permitted us to conclude that a distinctive species collected near Aquila, Michoacán is new to science. The purpose of this article is to describe this species.

Dioscorea megaphylla Ramírez-Amezcua, O. Téllez \& V.W.Steinm., sp. nov. (Figure 1). 
TYPE: Mexico, Michoacán, municipio de Aquila, $1.3 \mathrm{~km}$ al oeste de la salida a La Estanzuela, sobre la carretera AquilaCoalcomán, cañada al sur de la carretera, $18^{\circ} 36^{\prime} 34^{\prime \prime} \mathrm{N}$, $103^{\circ} 28^{\prime} 31^{\prime \prime} \mathrm{W}, 600 \mathrm{~m}$, pistillate with fruits, 30 July 2010 , V.W. Steinmann and Y. Ramírez-Amezcua 7116 (holotype: IEB; isotype: MEXU).

Herbaceous perennial climber to $15 \mathrm{~m}$ high; dioecious; flowering before the leaves develop. Stems left twinning, densely white tomentose when young, glabrate in age, papillose. Leaves alternate; petiole 7-44 $\mathrm{cm}$ long, sulcate, densely tomentose when young, tomentose to glabrescent in age; blade broadly ovate-orbicular, $16-60 \mathrm{~cm}$ long, $16-65 \mathrm{~cm}$ wide, densely tomentose when young, in age upper surface glabrous with a few scattered hairs along the primary veins, lower surface sparsely pilose with the hairs mostly along the primary veins and scattered, inconspicuous brown nectaries, base cordate with the lobes sometimes overlapping, apex of the young blades with a reddish-brown, glandular, sparsely pubescent deciduous portion that falls as the leaf ages, apex of the mature leaves acuminate or mucronulate, 11-19 primary veins, with a conspicuous network of parallel cross veins, margin entire. Pistillate inflorescences axillary, solitary, pendulous, $30-53 \mathrm{~cm}$ long, with 20-30 well-spaced flowers; rachis densely tomentose; bracts narrowly ovate, 4-5 mm long, $1.5 \mathrm{~mm}$ wide, densely tomentose, apex acute. Pistillate flowers sessile; tepals 6 , ovate $1.8-3 \mathrm{~mm}$ long, 0.9-1.2 mm wide, yellow, outer surface tomentose, inner surface glabrous, apex obtuse; staminodes 6 , ca. $0.3 \mathrm{~mm}$ long, inserted at the base of the tepals; styles $3,1.7-2 \mathrm{~mm}$ long, short and stout, emarginate at the apex. Staminate inflorescences axillary, in fascicles of 2-4, ascending to pendulous, 8-22.5 cm long, with 20-30 congested cymules of 2-4-flowers; rachis densely tomentose; bracts ovate, $1.5-2$ $\mathrm{mm}$ long, $1 \mathrm{~mm}$ wide, tomentose towards at the base, apex acute. Staminate flowers sessile; tepals 6, ovate, 1.9-2.3 $\mathrm{mm}$ long, 0.9-1.1 wide, yellow, outer surface tomentose, inner surface glabrous, apex obtuse, with scattered translucid glands; stamens 6, exserted, filaments free, inserted at the base of the tepals, $0.7-1.0 \mathrm{~mm}$ long, glabrous, anthers 0.4-0.5 mm long, 0.2-0.3 wide; pistillode obloid, $0.8-1 \mathrm{~mm}$ long, 3-lobed. Fruits on a stout pedicel $0.3-0.5 \mathrm{~mm}$ long, spreading from the rachis, ovoid to ellipsoid, triangular in cross-section with wing-like keels, 3.5-4.4 cm long, 1.8$2.5 \mathrm{~cm}$ wide, with persistent tepals at the pointed apex, tomentose with a glaucous appearance, less so along the keel. Seeds 2 per locule, flattened, 1.1-1.4 cm long, 0.6$0.9 \mathrm{~cm}$ wide, smooth, brown, with a hyaline, wing-like margin.

Distribution and ecology: Known only from the type locality, Dioscorea megaphylla occurs along the coastal foothills of the Sierra de Coalcomán in the municipality of Aquila, Michoacán, Mexico. It grows in rocky canyons and hillsides with tropical subdeciduous forest at elevations of 550-600 m; woody associates include Acalypha cincta Müll. Arg., Bouvardia sp., Brosimum alicastrum Sw., Bursera simaruba (L.) Sarg., Byttneria catalpifolia Jacq., Cecropia obtusifolia Bertol., Couepia polyandra (H.B.K.) Rose, Enterolobium cyclocarpum (Jacq.) Griseb., Louteridium brevicalyx A.T.Richardson, Myriocarpa sp., Oxandra lanceolata (Sw.) Baill., Phyllanthus coalcomanensis Croizat, Piper amalago L., Psychotria sp., Swartzia simplex (Sw.) Spreng., and Urera baccifera (L.) Gaudich.

Phenology: Flowering occurs at the end of the dry season in the months of May and June, and mature fruits are present from July to early September.

Additional specimens examined: Mexico, Michoacán, municipio de Aquila: $4 \mathrm{~km}$ al NE de Aquila, Cerro de la Mina, $18^{\circ} 36^{\prime} 40^{\prime \prime} \mathrm{N}, 103^{\circ} 28^{\prime} 45^{\prime \prime} \mathrm{W}, 05$ September 1996, $R$. Cuevas-G. 5195 (IBUG, ZEA); type locality, 31 August 2008 (pistillate with fruits), V.W. Steinmann, Y. RamírezAmezcua and J.M. Ramírez-Amezcua 6392 (IEB, ENCB); type locality, 31 May 2009 (staminate and pistillate with flowers), V.W. Steinmann and Y. Ramírez-Amezcua 6671 (IEB, ENCB).

\section{Discussion}

Dioscorea megaphylla is a distinctive species due to a number of features. As the specific epithet suggests, the leaves are very large. In fact they are the largest within the genus and measure as much as $60 \mathrm{~cm}$ long and $65 \mathrm{~cm}$ wide. The fruits are also notably large and reach $4.4 \mathrm{~cm}$ long. Unlike most members of the genus, flowering occurs at the end of the dry season on newly produced stems before the leaves mature. The only other species that we know to possess similar phenology is D. palmeri R.Knuth of sect. Apodostemon. The most peculiar trait of the new species is the presence of a reddish-brown, glandular structure at the apex of the young leaves (Figure 1E). This portion is quickly deciduous, and thus the apex of the mature leaf is a portion developmentally proximal to the apex of the leaf primordium.

Dioscorea megaphylla belongs to section Macrogynodium Uline, a taxon with 12 species characterized by the following features: staminate flowers with six stamens, conspicuous filaments, introrse anthers, and seeds possessing a peripheral winged margin (Knuth, 1924). Most of the species occur in Mexico and Central America, and only D. trifida L.f. and D. stegelmanniana R.Knuth are found in South America. Although some other South American species are morphologically similar to those of section Macrogynodium, these belong to other sections, e.g., sect. Chondrocarpa Uline.

The new species is closely related to Dioscorea nelsonii Uline ex R.Knuth and D. carpomaculata O.Téllez \& 

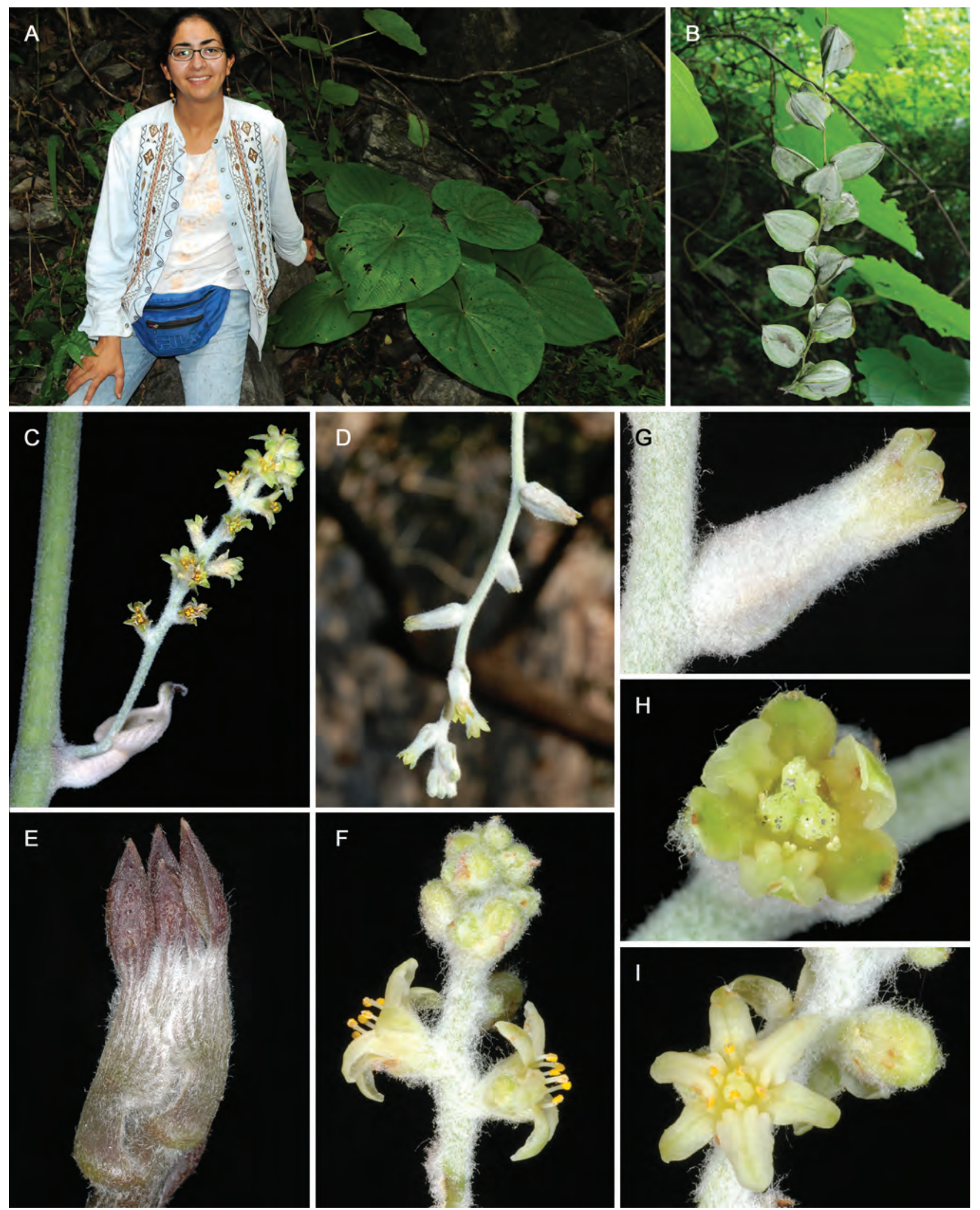

Figure 1. A. Habit of a juvenile plant; B. Infrutescence; C. Staminate inflorescence; D. Pistillate inflorescence; E. Young leaves showing the reddish-brown, glandular structure at the apex; F. Staminate flowers, lateral view, and apical portion of the staminate inflorescence; G. Pistillate flower, lateral view; H. Pistillate flower, viewed from above; I. Staminate flower viewed from above. 
B.Schubert, with which it shares the following characteristics: large fruits (the largest in the section), pubescent leaves, and a pistillode of similar size and shape. However, it is separated from both of these by a number of features such as its larger leaves, tomentose pubescence and larger, glaucous fruits. The new species could be confused with D. subtomentosa Miranda of sect. Combilium Prain \& Burkill due to its tomentose pubescence, but the latter has spines on the young stems near the rhizomes, a pair of spines at the base of the petiole, and purple flowers. It also resembles $D$. gallegosii Matuda due to its glaucous fruits; however, the latter belongs to sect. Apodostemon Uline and differs in possessing purple flowers with sessile stamens.

Dioscorea megaphylla is frequent at the type locality. However, most individuals are less than $1 \mathrm{~m}$ tall and neither twinning nor reproductive (Figure 1A). Only a small proportion of plants develop elongated stems that allow them to climb to the canopy. We hypothesize that these smallstatured plants are juveniles and that only after some years of growth do they reach maturity and develop a tuber with sufficient reserves to permit them to attain their maximum height of up to $15 \mathrm{~m}$ tall.

\section{Acknowledgements}

We thank Pablo Carrillo Reyes for bringing to our attention the collection made by Ramón Cuevas; José Manuel Ramírez Amezcua, and Eloisa Amezcua for help with fieldwork; Damián Piña Bedolla for preparing the figure; the herbarium IBUG for access to their collections; the program DGAPA-PAPIIT for support of the project "Sistemática, Biogeografía y Conservación de Dioscorea en México" (IN-225010); Ramona L. Walls and Lauren Raz for reviewing the manuscript and providing many useful comments and suggestions; and funding support to the Instituto de Ecología, A.C. (account number 20006) from the Mexican Consejo Nacional de Ciencia y Tecnología and from the Comisión Nacional para el Conocimiento y Uso de la Biodiversidad.

Received: June 2, 2012

Accepted: July 12, 2012

\section{Literature cited}

Al-Shehbaz I.A. and Schubert B.G. 1989. The Dioscoreaceae in the Southeastern United States. Journal of the Arnold Arboretum 70:57-95.

Caddick L.R., Wilkin P., Rudall P.J., Hedderson T.A.J. and Chase M.W. 2002. Yams reclassified: a recircumscription of Dioscoreaceae and Dioscoreales. Taxon 51:103-114.

Govaerts R., Wilkin P. and Saunders R.M.K. 2007. World Checklist of the Dioscoreales: Yams and their Allies. Royal Botanic Gardens Kew, Kew.

Knuth R. 1924. Dioscoreaceae. In Engler. Das Pflanzenr. 87 (IV. 43). pp. 1-387, H.R. Engelmann (J. Cramer). Leipzig.

Matuda E. 1953. Las Dioscóreas de México. Anales del Instituto de Biología Universidad Nacional Autónoma de México, Serie Botánica 24:279-390.

Schubert B.G. 1989. Dioscoreaceae. In: McVaugh R. and Anderson W.R. Eds. Flora Novo-Galiciana: A Descriptive Account of the Vascular Plants of Western Mexico, Volume 15 Bromeliaceae to Dioscoreaceae, pp. 355-388, University of Michigan Press, Ann Harbor.

Téllez-V. O. 1997. Nomenclatural changes in Mexican Dioscoreaceae and Leguminosae. Contributions Universitiy of the Michigan Herbarium 21:309-313.

Téllez-V. O. and Schubert B.G. 1987. Una nueva especie del género Dioscorea (Dioscoreaceae) del estado de Querétaro, México. Annals of the Missouri Botanical Garden 74:539-541.

Téllez-Valdés O. and Schubert B.G.1991. Especies nuevas y colecciones notables de Dioscorea (Dioscoreaceae) en Mesoamérica. Annals of the Missouri Botanical Garden 78:245-253.

Téllez-V. O. and Schubert B.G. 1996. Dioscoreaceae. In: Davidse G., Sousa M. y Chater O. Eds. Flora Mesoamericana Volumen 6. Alismataceae a Cyperaceae, pp. 54-65, Universidad Nacional Autónoma de México/Missouri Botanical Garden/The Natural History Museum, Mexico D.F.

Téllez-Valdés O. and Geeta R. 2007a. Dioscorea howardiana, a new species in Dioscorea section Trigonobasis (Dioscoreaceae). Brittonia 59:370-373.

Téllez-Valdés O. and Geeta R. 2007b. Sinopsis taxonómica de la sección Apodostemon (Dioscorea - Dioscoreaceae). Revista Mexicana de Biodiversidad 78:265-279.

Walls R.L. 2009. Form, function, and phylogeny: Angiosperm leaf trait evolution, with a case study in the genus Dioscorea. Ph.D. dissertation, State University of New York at Stony Brook, New York. 152 pp. 